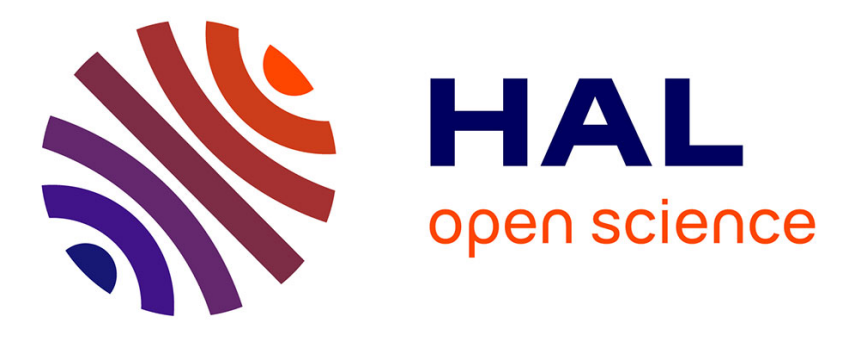

\title{
Cost-performance framework for the assessment of Modular Multilevel Converter in HVDC transmission applications
}

Nathan Evans, Piotr Dworakowski, Mohammed Al-Kharaz, Sneha Hegde, Elie Perez, Florent Morel

\section{To cite this version:}

Nathan Evans, Piotr Dworakowski, Mohammed Al-Kharaz, Sneha Hegde, Elie Perez, et al.. Costperformance framework for the assessment of Modular Multilevel Converter in HVDC transmission applications. IECON 2019 - 45th Annual Conference of the IEEE Industrial Electronics Society, Oct 2019, Lisbon, Portugal. pp.4793-4798, 10.1109/IECON.2019.8927117 . hal-02432355

\section{HAL Id: hal-02432355 \\ https://hal.science/hal-02432355}

Submitted on 8 Jan 2020

HAL is a multi-disciplinary open access archive for the deposit and dissemination of scientific research documents, whether they are published or not. The documents may come from teaching and research institutions in France or abroad, or from public or private research centers.
L'archive ouverte pluridisciplinaire HAL, est destinée au dépôt et à la diffusion de documents scientifiques de niveau recherche, publiés ou non, émanant des établissements d'enseignement et de recherche français ou étrangers, des laboratoires publics ou privés. 


\title{
Cost-performance framework for the assessment of Modular Multilevel Converter in HVDC transmission applications
}

\author{
Nathan Evans ${ }^{1,2}$, Piotr Dworakowski ${ }^{1,3}$, Mohammed Al-Kharaz ${ }^{1}$, Sneha Hegde ${ }^{1}$, Elie Perez ${ }^{1}$, Florent Morel ${ }^{1,4}$ \\ ${ }^{1}$ SuperGrid Institute SAS, Villeurbanne, France \\ 2nathan.evans@supergrid-institute.com \\ (iD): 0000-0002-6893-0103 \\ 4 (iD): 0000-0003-3098-7806
}

\begin{abstract}
This article proposes a methodology of Cost-Performance Assessment (CPA) enabling the efficient cost evaluation required for the Cost-Benefit Analysis (CBA). The proposed method is applied for the Modular Multilevel Converter (MMC) in offshore wind high voltage direct current (HVDC) transmission. Thanks to the developed model, an analysis of submodule voltage rating is performed demonstrating the interest of this methodology in the evaluation of new technologies for HVDC transmission. The analysis shows that increasing the submodule (SM) voltage could lead to savings in the MMC cost and weight.
\end{abstract}

Keywords - cost-performance assessment, offshore wind, transmission, HVDC, MMC, VSC, power transformer, submodule, IGBT, film capacitor, cost-benefit analysis, LCOE, OEM.

\section{INTRODUCTION}

The Cost-Benefit Analysis (CBA) allows to evaluate the interest of projects of future investments and to compare different solutions [1] - [3]. A CBA is often expressed in monetary terms where the cost is calculated taking into account the investment and operational cost and the benefit may take into account the socioeconomic welfare. This forms one of many criteria identified in the ENTSO-E guidelines document [4]. The choice of HVDC transmission for offshore wind farms results in fact from the CBA considering the cost of the link and offered benefits like the reduced energy cost [5].

The modular multilevel converter (MMC) has become the reference in HVDC transmission where the Voltage Source Converters (VSC) are required [6], [7]. To investigate opportunities for innovation in this area, a power electronic cost-performance analysis should be carried out.

The energy cost is usually measured thanks to the Levelized Cost of Energy (LCoE). Power converters, such as the MMC, contribute substantially to the LCoE of the HVDC transmission connection of offshore wind farms. Given that a power converter of this type, in the class of 600-1000 MW, can cost several tens of million euros, detailed cost modelling can help to identify and understand valuable areas of innovation for researchers, original equipment manufacturers (OEMs) and $1^{\text {st }}$ tier manufacturers alike.

This article, therefore, proposes a methodology of CostPerformance Assessment (CPA) which enables this cost evaluation required to be made and used as input for a complete CBA. The CPA does not evaluate the whole benefit, though it is a powerful tool in the comparison of alternative solutions. It may also provide a basis for design optimization studies.
The cost-performance indicators of power converters are discussed in Section II. The modelling methodology is outlined in Section III. An MMC case study is highlighted and its analysis is outlined in Section IV. An analysis of a SM voltage variation is given in Section V. Finally, the conclusions and perspectives are given in Section VI.

\section{COST-PERFORMANCE INDICATORS OF POWER CONVERTERS}

The LCoE takes into account the investment and operating cost and the amount of energy produced:

$$
\mathrm{LCoE}=\frac{\sum_{t=1}^{n} \frac{I_{t}+O_{t}+F_{t}}{(1+r)^{t}}}{\sum_{t=1}^{n} \frac{E_{t}}{(1+r)^{t}}}
$$

where:

$I_{t}$ investment cost at year $t$

$O_{t}$ operating cost at year $t$

$F_{t}$ fuel cost of year $t$ (zero for wind power)

$E_{t}$ produced energy at year $t$

$r$ discount rate

$n$ number of years during which the system is exploited.

The investment cost, also named the Capital Expenses (CapEx), is related to the purchase of the converter and converter station components, installation, commissioning, construction, and decommissioning. The investment cost should take into account at least the costs incurred due to:

- Engineering - involving all the project design activities,

- Production - taking into account the cost of subsystem/ system assembly,

- Component purchase - based on the amount paid for acquiring a given component.

The Operating Expenses (OpEx) are related to the converter power loss during operation, and the converter maintenance costs during its operational lifetime. It is considered in [8], [9] that at least the following costperformance indicators shall be considered when evaluating and designing a power converter:

- Converter cost structure,

- Size and weight,

- Power loss,

- Reliability.

The following subsections give details on these indicators and explains why the investment cost for offshore wind is highly sensitive to both weight and volume while the power 
converter operating cost is sensitive to both power loss and also reliability.

\section{A. Converter cost structure}

The cost structure of the power conversion equipment is different for every manufacturer as the supply chain strategy varies between them. Taking the CapEX as an example, one manufacturer can produce its own IGBT power module, thus involving engineering/production/component cost, whereas another can buy a ready product, thus incurring the component cost only.

\section{B. Converter Size and Weight}

The size and weight of the converter and the station equipment influence the civil works required for their installation. These two parameters also have an indirect impact on the investment cost especially when installing the converter on a platform, which is the case in Offshore Wind Farms (OWF) [10] - [12].

\section{Converter Power Loss}

The power loss has an impact on the converter design and cooling management [13] as well as the energy produced [14]. For example, the typical $1 \%$ of power loss in $1 \mathrm{GW}$ converter station stands for up to 88TWh of energy loss per year, which is equivalent to approximately 4 million euros (using an energy price of $44 € / \mathrm{MWh}[15])$.

\section{Converter Reliability}

The reliability of power converter impacts the HVDC transmission downtime and repairs, influencing the operating cost and the energy produced [16] - [19].

\section{THE PROPOSED MODELLING APPROACH OF MMC STATIONS IN HVDC}

\section{A. The $M M C$}

In offshore wind farm HVDC transmission systems, the VSC represents the reference case for power conversion in this environment because of its ability in active and reactive power handling (four quadrant operation) and its black-start capability [24].

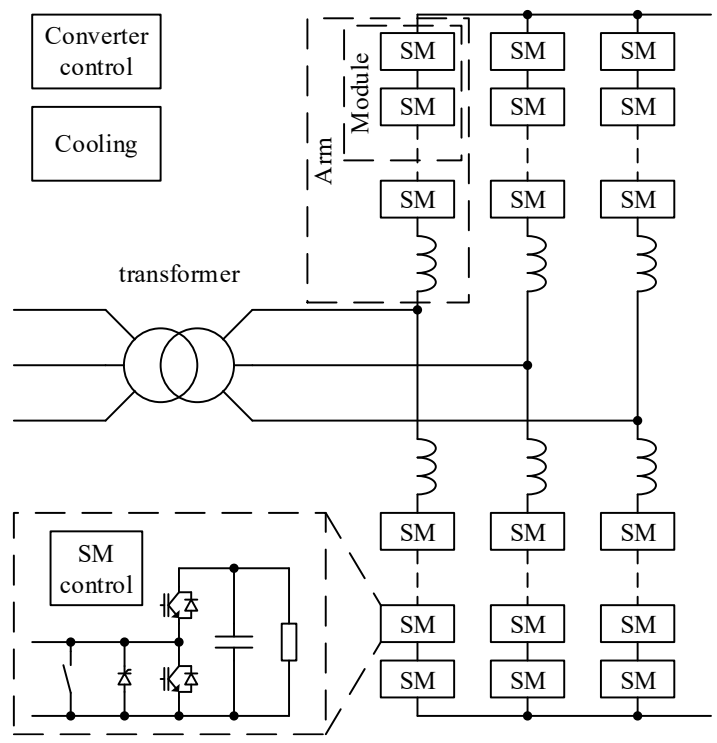

Fig. 1. MMC converter station line diagram with major station equipment (SM = submodule)

Of the family of VSC, the MMC (Fig. 4) offers [6], [25]:
- Synthesis of a sinewave with low harmonic distortion at low switching frequencies, allowing a reduction in filter requirements and power losses,

- Modularity in structure that allows easy adaptation to different voltage and power levels, enabling a reduction in costs associated with engineering, production, and component,

- Hardware redundancy which allows uninterrupted operation under component failure, leading to an increase in converter operational time.

\section{B. The CPA Modelling Approach}

The modelling approach to cost-performance assessment must take into account the amount of available information in the function of power converter Technology Readiness Level (TRL) which varies from 1-9. At TRL1 (converter conceptualization stage), only a rough CPA can be performed with a limited precision. Whereas, at TRL5 (converter prototype development stage) a detailed CPA is possible with a sufficient precision required for product development.

Two modeling approaches are possible: the bottom-up approach and the top-down approach. In the bottom-up approach (Fig. 2), the power converter system is divided into several subsystems which are further divided to obtain lower level of components such as IGBT, capacitors etc. The data of the individual component are aggregated together at the lower level to obtain the data of the higher level.

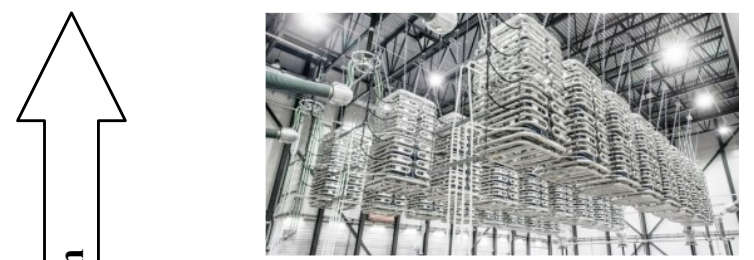

System - Modular Multilevel Converter [ABB]

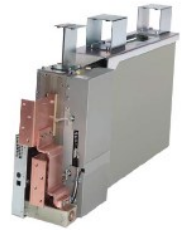

Subsystem - MMC submodule [Siemens]

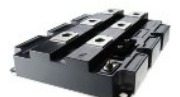

Component - IGBT pack [Mitsubis hi]

Fig. 2. Cost-performance modelling approach - bottom-up (images taken from [20])

In the top-down approach (Fig. 3) there is the high-level data that is aggregated and anonymized. This high-level data is often published by authorities or consulting companies. The high-level data is not sufficient in the CPA of new technologies as we do not know the system breakdown structure and the component share in the overall CPA, but this data can provide a benchmark for the results of a costperformance assessment.

In this article the bottom-up approach is proposed for model development, more adapted to low-TRL studies, whilst 
the top-down approach is proposed for model validation, which can be used at both low- and moderate-TRL stages in power converter development. Both are based on a power converter station breakdown structure.

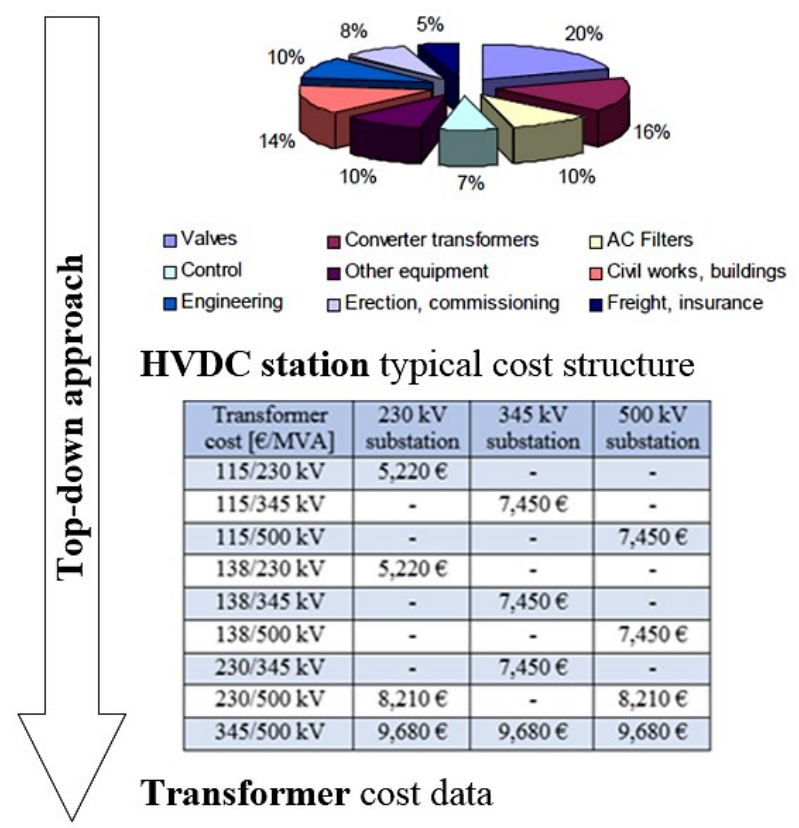

Fig. 3. Cost-performance modelling approach - top-down (typical HVDC station costs [21] and typical power transfomer costs [22])

For a complete cost-performance analysis, of the station components to which the cost-performance parameters have a non-negligible sensitivity should be included. For example, the MMC SM component requirements will have a big impact on the station cost, the footprint and also the station weight.

\section{Converter Component Breakdown Structure}

The converter component breakdown structure, based upon power converter structure and component information published in the literature [23] offers the hierarchical tree structure allowing to identify the elementary components. Each low-level component is associated with the cost-performance indicators presented in the Section II. The higher level is simply calculated using algebraic operations based on lower level data. The breakdown depth can be adjusted according to the required precision. The raw data of elementary components is gathered in a database which is the heart of the CPA.

\section{Converter CPA Model Implementation}

The model can be implemented in any programming or computational environment. The authors have successively utilized Excel, Python and MATLAB. Excel offers the easiest and fastest implementation but does not allow an easy traceability and configuration management. Python has particular interest because of the way that it handles matrices and also in the fact that it is an open-source language. MATLAB requires a larger initial investment but comes with powerful programming and interface functionalities.

The model inputs are at least the converter station voltage and power, and the parameters are related to the technology such as SM voltage or IGBT used (see Fig. 4). Thanks to the database for each component (used to store information about component price, size, reliability, etc.) the cost-performance indicators are calculated and further aggregated in the converter breakdown structure. The results present the overall system cost-performance. Eventually an optimization algorithm can be added allowing to adjust the parameters, thus optimizing the converter design.

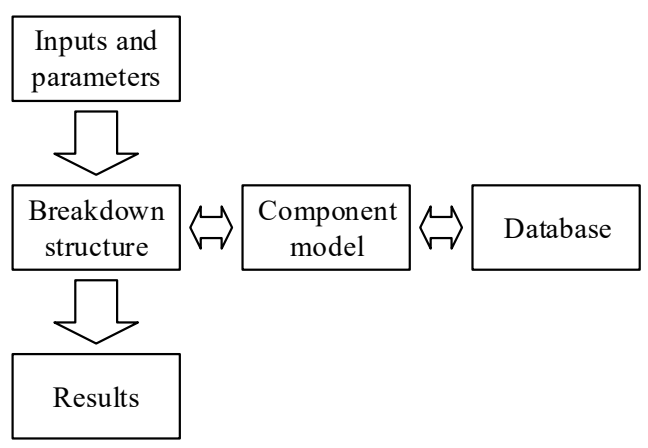

Fig. 4. Cost-performance model implementation

\section{E. Statement of hypothesese}

Given the potential complexity of the CPA model, it is important to well define the assumptions that are made within the model. Here in the following case study, for example, it is assumed that the energy storage in the MMC is fixed according to its power rating.

\section{F. Parameter Sensitivty Analysis}

Once the model has been constructed, it is ready to be evaluated. The main aim of this evaluation is to make a study of the effects that varying the model inputs can have on the cost-performance parameters.

\section{Modular MultileVel CONVERTER CASE STUdy}

This technology is dominant within Offshore Wind Farm (OWF) HVDC connections and is the reference for HVDC transmission stations in the class of 600-1000 MW [26].

\section{A. MMC Model Inputs and Parameters}

Out of the existing and operational projects of this class, BorWin 2 provides an excellent example in that it is both recent and has had sufficient enough data published about it to be used to form the inputs of a case study (TABLE I).

TABLE I. BORWIN2 OFFSHORE STATION CASE STUDY INPUT DATA [27]

\begin{tabular}{|l|l|l|l|}
\hline Parameter & Variable & Value & Unit \\
\hline Rated power & $\mathrm{P}$ & 800 & $\mathrm{MW}$ \\
\hline AC voltage & $\mathrm{Vac}$ & 155 & $\mathrm{kV}$ \\
\hline DC voltage & $\mathrm{Vdc}$ & \pm 300 & $\mathrm{kV}$ \\
\hline DC current & $\mathrm{Idc}$ & 1320 & $\mathrm{~A}$ \\
\hline IGBT breakdown voltage & $\mathrm{Vbr}$ & 4.5 & $\mathrm{kV}$ \\
\hline
\end{tabular}

\section{B. MMC Component Breakdown Structure}

A component breakdown structure of the converter station should include the following components: power converter; HVDC transformers; cooling system; protection; filtering; auxiliary systems; and, the platform. The important CPA parameters to assess here would be the station equipment electrical power densities, by volume and by weight, because of the sensitivity in the offshore environment to these two parameters; the individual contribution to the overall cost of the station by the transformers $(\sim 10-15$ million euros, assuming two 600 MVA transformers in parallel [22]), the platform, and the protection system are significant enough to be studied in their own right. 
For the sake of brevity it is only the MMC arm components that are studied in this paper (see Fig. 5).

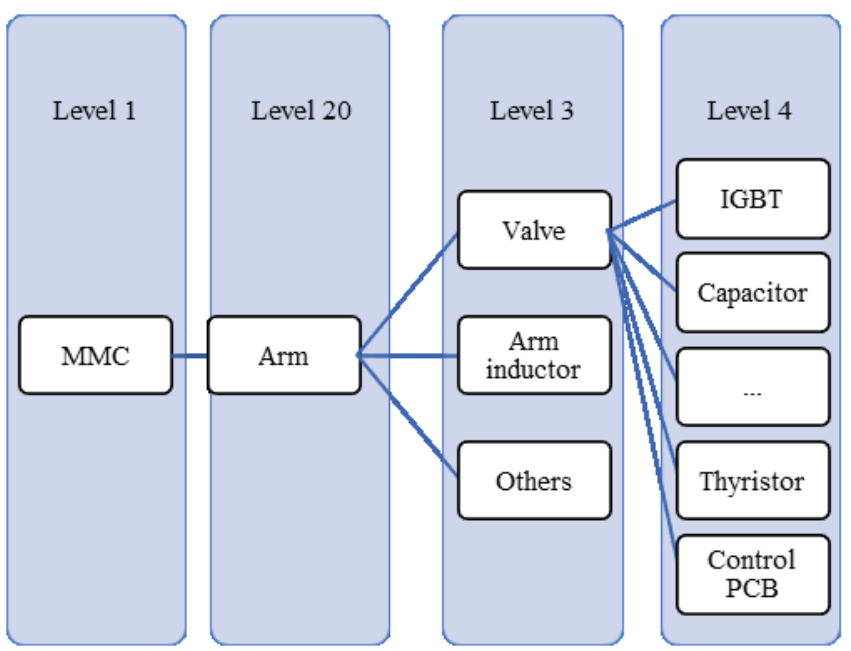

Fig. 5. The MMC arm component breakdown structure. The IGBT and capacitor weight and cost models are considered functions of the SM cell voltage; all other components are modelled as constants

The contribution to the overall cost and weight of the converter station of the MMC modules makes them an important aspect of a CPA. For example, the component cost breakdown of the MMC power converter shows that the largest contribution to the weight of the MMC arm is found to be made by the MMC modules (Fig. 6, left). Also, the largest contribution to the estimated arm cost comes from the module (Fig. 6, right). Therefore, the SM components are studied here in more detail.
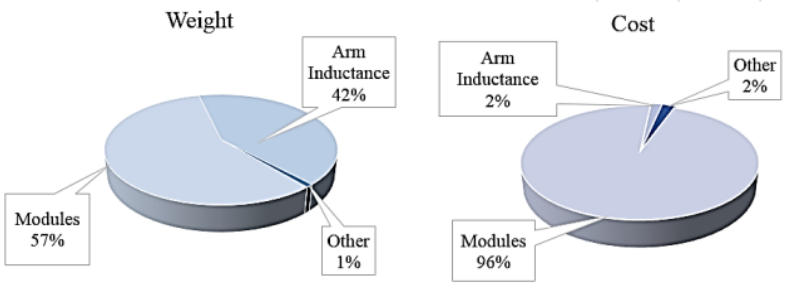

Fig. 6. The percentage contributions of MMC arm components to the arm weight (left of figure) and to the arm cost (right of figure) with Vcell $=$ $2.5 \mathrm{kV}(\mathrm{Vbr}=4.5 \mathrm{kV})$

\section{MMC Component Modelling}

Thin film metallized polypropylene film (MPPF) capacitors are the reference technology for the MMC SM due to their low cost, low loss and stability in wide temperature and frequency range [28]. Consequently, this technology is represented in the case study model. The data stored in the CPA database for the film capacitor includes a model of the capacitor mass as a function of its energy storage and a model of the capacitor cost as a function of capacitor mass and has been taken from manufacturer datasheets. The weight model is valid for capacitors with a rated current of $250 \mathrm{~A} \mathrm{rms}$.

The total weight of the capacitors in the submodule can be found by:

$$
w t_{c a p, s m}\left(W_{s m}\right)=n_{c p}\left(3.57 W_{s m}+5.92\right)[k g]
$$

where $n_{c p}$ is the number of capacitors in parallel and $W_{s m}$ is the submodule energy storage value in $\mathrm{kJ}$. The cost of the total required capacitance can be found by (3).

$$
\operatorname{cost}_{\text {cap }}\left(w t_{\text {cap }}\right)=40 w t_{\text {cap }}[€]
$$

The IGBT used in MMCs in HVDC applications can range in voltage from 3.3-6.5 kV [29], [30]. There is a number of suppliers of IGBT power modules (PM). For this study, a model of the IGBT PM weight, $w t_{I G B T, s m}$, has been fitted to components in this voltage range. This model is a function of the derated breakdown voltage of the IGBT, $V_{\text {derated }}$, which has the following relationship with the IGBT breakdown voltage, $V_{B r}$ :

$$
V_{\text {cell }}=V_{\text {derated }}=0.56 \times V_{B r}[\mathrm{~V}]
$$

where $V_{\text {cell }}$ is the MMC submodule voltage. The IGBT PM weight is modelled by (5).

$$
w t_{\text {IGBT,sm }}\left(V_{\text {cell }}\right)=0.9 \times 10^{-3} V_{\text {cell }}-0.43[\mathrm{~kg}]
$$
of (6).

The cost model fitted to IGBT data is expressed in the form

$$
\operatorname{cost}_{\text {IGBT .sm }}\left(V_{\text {cell }}\right)=1.27 V_{\text {cell }}-960[€]
$$

The MMC loss model utilises the loss and characterisitcs commonly found in the component datasheet. Reliability calculations in a static form use the component failure-in-time (FIT) rate, which can also be found in the component datasheet. Neither parameters are calculated in this paper and so these models are not detailed.

\section{RESULTS OF A SUBMODULE VOLTAGE VARIATION STUDY}

The following section presents the results of a study on the variation of the submodule voltage. This analysis is interesting when evaluating the use of new technologies, as Silicon Carbide (SiC).

\section{A. MMC Submodule Cost-Performance Assessment Hypothesis}

In the analysis made in the following CPA, the main hypothesis held is that the minimum global energy storage requirement of the $\mathrm{MMC}$ is fixed, the value of which is chosen based upon the maximum permissible fluctuation in the submodule dc voltage. The energy stored within the MMC converter is normally expressed as a function of the active power transfer requirement [31].

According to [32], for an MMC that employs sinusoidal pulse-width modulation (SPWM) [14] the expected figure, when the converter is operating in a worst-case scenario (that is to say ac grid voltage is $0.9 \mathrm{pu}$ and the phase shift between the grid voltage and grid current $\varphi=90^{\circ}$ ) the total energy stored in the MMC should be $39 \mathrm{~kJ} / \mathrm{MVA}$ or $21 \mathrm{~kJ} / \mathrm{MVA}$, for triplen harmonic injection. Assuming that the latter control approach is used in the model in this case study, a value of $21 \mathrm{~kJ} / \mathrm{MVA}$ is chosen.

The assumptions that are made in [32] are also made here. That is to say that the capacitor voltage ripple is fixed at $10 \%$. Furthermore, that the operation of the MMC is considered in steady state only, that the energy stored in the inductors in the converter is neglected, and that the storage in the MMC in ratio with the apparent power $S$ is given as in (7).

$$
\frac{W_{M M C, \min }}{S}=21\left[\frac{\mathrm{kJ}}{M V A}\right]
$$

\section{B. Power Converter Electro-Technical Model}

To identify the number of parallel capacitors required in the submodule bank of capacitors, $n_{c p}$, an expression of the rms current is required. The SM capacitor bank will be 
subjected to currents with frequencies at the line frequency and double the line frequency [33]. The rms value can be found by evaluating (8).

$$
\begin{gathered}
I_{c p, r m s}^{u, l}(\varphi)=\sqrt{\frac{\sqrt{\left(a_{1}^{u, l}\right)^{2}+\left(b_{1}^{u, l}\right)^{2}}}{2}+\frac{\sqrt{\left(a_{2}^{u, l}\right)^{2}+\left(b_{2}^{u, l}\right)^{2}}}{2}} \\
I_{c p, r m s}^{u, l}(\varphi)\left\{\begin{array}{l}
a_{1}^{u, l}=-\frac{I_{d c} M}{6}+\frac{\widehat{I_{a c}} \cos (\varphi)}{4} \\
b_{1}^{u, l}=\frac{\widehat{I_{a c}} \cos (\varphi)}{4} \\
a_{2}^{u, l}=\frac{\widehat{I_{a c}} \operatorname{Msin}(\varphi)}{8} \\
b_{2}^{u, l}=-\frac{\widehat{I_{a c}} \operatorname{Msin}(\varphi)}{8}
\end{array}\right.
\end{gathered}
$$

Where the modulation index, $M=\frac{2 \widehat{V_{a c}}}{V_{d c}}$. Using (8) to calculate the capacitor rms current, the number of parallel required capacitors to ensure that the value of rated current for the capacitor model is not exceeded, $n_{c p}=3$.

Using the relationship between capacitance, voltage and energy applied at the submodule level, we can define the total energy storage requirement of the SM in each arm of the MMC as in (10).

$$
W_{\text {arm, } \min }=\frac{1}{2} n_{s m, \text { arm }} n_{c p} C_{\text {cap }} V_{\text {cell }}^{2}[\mathrm{~J}]
$$

where $n_{s m, M M C}$ is the number of submodules in the three phases of the MMC and, $C_{c a p}$, is the capacitance of the individual capacitors used in the capacitor bank model and $n_{c p}$ is the number of capacitors in parallel. The number of SM is normally expressed as in (11), where $k_{r}$ is the coefficient used to add redudancy to the number of SM in the MMC here $\left(k_{r}=1.1\right)$.

$$
n_{\text {sm,arm }}=\frac{k_{r}}{2} \times \frac{V_{D C}}{V_{\text {cell }}}
$$

Substituting (10) and (11) into (9) and rearranging this equation into a function of the cell voltage gives (12).

$$
V_{\text {cell }}=10 \times 10^{-3} \frac{s}{c_{c a p} V_{D C}}[\mathrm{~V}]
$$

\section{Parameter Sensitivity Analysis}

Once the models of the components have been defined, the sensitivity of the CPA parameters to variation of input values can be made. In this cost-performance assessment, the submodule voltage was varied to see the impact that this would have on the MMC arm cost and weight.

\section{Results}

In Fig. 7 and Fig. 8, the impact of the variation of the SM voltage can be seen on the MMC arm cost and weight, respectively. The results indicate that there is a sensitivity in these two parameters to an increase in the SM cell voltage.

As can be seen in those figures, with the case study input data taken from TABLE I, the increasing the voltage class of the IGBT could yield decreases in both the cost and weight of the MMC arm. Therefore, the impact of this on the weight and volume should be carefully monitored.

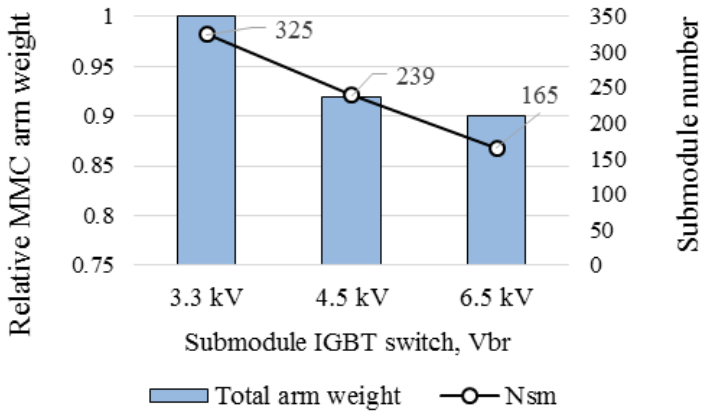

Fig. 7. The relative weight of the MMC arm with different IGBT voltage classes

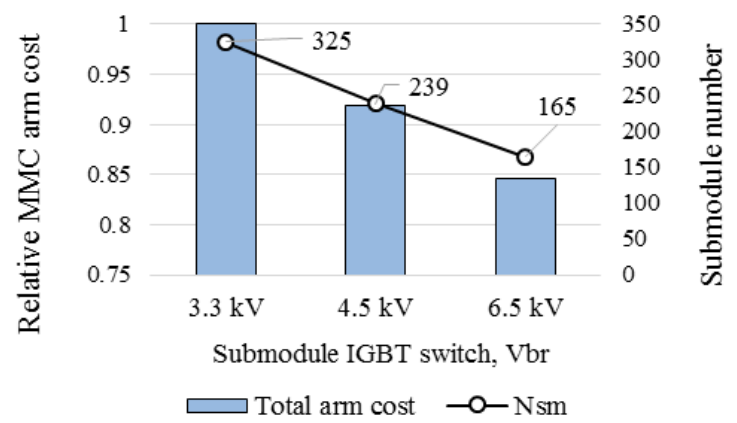

Fig. 8. The relative costs (CapEx) of the MMC arm with different IGBT voltage classes

\section{CONCLUSION AND PERSPECTIVES}

A methodology of HVDC converter station CPA was proposed. It is based on cost, size, weight, power loss, and reliability indicators. The method was applied for the Modular Multilevel Converter and the analysis of submodule voltage rating was performed. The analysis indicated that increasing the IGBT voltage class could lead to savings in the MMC cost and weight.

The CPA is essential in the evaluation of new technology concepts. It can be applied in the study of innovative HVDC converter topologies, such as the Series Bridge Converter [34], which seems an interesting candidate to challenge the MMC. Moreover, it can provide important information for the cost-benefit analysis allowing to evaluate the interest of DC-DC converters [35] for HVDC transmission. The CPA requires an expert knowledge on the analyzed system and a solid component database. Extended with an optimization algorithm it becomes a powerful tool in the new product development.

To explore further the costs and benefits of increasing this voltage, the reliability, the power loss, and the submodule size should be introduced to the model. The positive impact that reducing the number of submodules could have on the reliability of the MMC would be interesting to study further. On the other hand, the increase in the cell voltage may also lead to increased IGBT failure, due to cosmic ray effects, and so there may be an optimal point to be located between reliability and the cell voltage.

The current rating of the IGBT pack should also be introduced as a variable in further modelling work and its isolation material should be modelled as voltage-dependent. Additionally, the thryistor model should be given as a function of voltage. 
Given the impact that the control system can have on the operation of the converter, the effect of using nearest level modulation (NLM) on the cell capacitor sizing should be studied further. A comparison between the MMC and the twolevel series connected VSI may also have interest in being made.

\section{ACKNOWLEDGMENT}

This work was supported by a grant overseen by the French National Research Agency (ANR) as part of the "Investissements d'Avenir" Program (ANE-ITE-002-01).

\section{REFERENCES}

[1] S. Gasnier, V. Debusschere, S. Poullain and B. François, "Technical and economic assessment tool for offshore wind generation connection scheme: Application to comparing $33 \mathrm{kV}$ and $66 \mathrm{kV}$ AC collector grids authors," in 2016 18th European Conference on Power Electronics and Applications (EPE'16 ECCE Europe), 2016.

[2] L. Castro-Santos, E. Martins and C. G. Soares, "Cost assessment methodology for combined wind and wave floating offshore renewable energy systems," Renewable Energy, vol. 97, pp. 866-880, 2016.

[3] P. Lakshmanan, J. Liang and N. Jenkins, "Assessment of collection systems for HVDC connected offshore wind farms," Electric Power Systems Research, vol. 129, pp. 75-82, 2015.

[4] ENTSO-E, "Guideline for Cost Benefit Analysis of Grid Development Projects,"2018.[Online].Available:https://www.entsoe.eu/news/2018/ 10/12/commission-approves-2d-entso-e-guideline-for-cost-benefitanalysis-of-grid-development-projects/. [Accessed 01 /04 /2019].

[5] H. Wang and M. Redfern, "The advantages and disadvantages of using HVDC to interconnect AC networks," in 45th International Universities Power Engineering Conference UPEC2010, 2010.

[6] A. Lesnicar and R. Marquardt, "An innovative modular multilevel converter topology suitable for a wide power range," in 2003 IEEE Bologna Power Tech Conference Proceedings, 2003.

[7] J. M. Jesus and R. Castro, "HVDC Connection of Offshore Wind Parks : VSC vs LCC with STATCOM," in Power Systems Transients, Delft, Netherlands, 2011.

[8] J. W. Kolar, J. Biela, S. Waffler, T. Friedli and U. Badstuebner, "Performance trends and limitations of power electronic systems," in 2010 6th International Conference on Integrated Power Electronics Systems, 2010.

[9] A. Hillers, M. Stojadinovic and J. Biela, "Systematic comparison of modular multilevel converter topologies for battery energy storage systems based on split batteries," in 2015 17th European Conference on Power Electronics and Applications (EPE'15 ECCE-Europe), 2015.

[10] B. Volov, "Transformers for Offshore Wind Platforms: Expected Problems and Possible Approaches," in 8th International Workshop on Large-Scale Integration of Wind Power into Power Sytems, Germany, 2009.

[11] T. Nakanishi and J. Itoh, "High Power Density Design for a Modular Multilevel Converter With an H-Bridge Cell Based on a Volume Evaluation of Each Component," IEEE Transactions on Power Electronics, vol. 33, pp. 1967-1984, 32018.

[12] T. A. Toshon, "Estimation of Power Density of Modular Multilevel Converter Employing Set Based Design," Florida State University, Florida, 2017.

[13] P. S. Jones and C. C. Davidson, "Calculation of power losses for MMCbased VSC HVDC stations," in 2013 15th European Conference on Power Electronics and Applications (EPE), 2013.

[14] P. Ladoux, N. Serbia, P. Marino and L. Rubino, "Comparative study of variant topologies for MMC," 2014 International Symposium on Power Electronics, Electrical Drives, Automation and Motion, pp. 659-664, 2014.

[15] RTE, "Données de marché," [Online]. Available: https://www.rtefrance.com/fr/eco2mix/donnees-de-marche. [Accessed 01/04/2019].
[16] ENTSO-E, "Improving HVDC System Reliability," 2018. [Online]. Available: https://www.entsoe.eu/2018/12/10/improving-hvdcsystem-reliability/. [Accessed /01/04 2019].

[17] B. Wang, X. Wang, Z. Bie, P. D. Judge, X. Wang and T. C. Green, "Reliability Model of MMC Considering Periodic Preventive Maintenance," IEEE Transactions on Power Delivery, vol. 32, pp. 1535-1544, 62017.

[18] R. R. Soman, T. A. Toshon, M. O. Faruque and M. Steurer, "Reliability Metric Influenced Full Factorial Design Evaluation," in ASNE AMTS 2018, Philadelphia, 2018.

[19] V. Najmi, J. Wang, R. Burgos and D. Boroyevich, "High reliability capacitor bank design for modular multilevel converter in MV applications," in 2014 IEEE Energy Conversion Congress and Exposition (ECCE), 2014.

[20] M. Billmann, O. Kreutzer and M. Nagelmüller, "Modular Multilevel Converters: State of the Art and Future Progress," IEEE Power Electronics Magazine, vol. 5, pp. 24-31, 122018.

[21] A. Russo, "Design of a Power Transformer and HVDC Transmission System," PhD dissertation, University of Padua, Padua, 2011.

[22] Black and Veatch Corporation, "Capital costs for transmission and substations," $2014 \quad$ [Online] Available: https://www.wecc.org/Reliability/2014_TEPPC_Transmission_CapC ost_Report_B+V.pdf

[23] T. A. Toshon, R. R. Soman, C. W. M. I. M. O. F. and M. S. "Component Level Decomposition Approach to Develop Selection Metrics for Shipboard Power Converter Systems," in ASNE ISS 2017, Philadelphia, 2017.

[24] R. L. Sellick and M. Åkerberg, "Comparison of HVDC Light (VSC) and HVDC Classic (LCC) site aspects, for a 500MW 400kV HVDC transmission scheme," in 10th IET International Conference on AC and DC Power Transmission (ACDC 2012), 2012.

[25] D. Van Hertem, O. Gomis-Bellmunt and J. Liang, HVDC Grids: For Offshore and Supergrid of the Future, Wiley, 2016.

[26] P. Menke, R. Zurowski, T. Christ, S. Seman, G. Giering, T. Hammer, W. Zink, F. Hacker, D. Imamovic, J. Thisted, P. Brogan and N. Goldenbaum, "2nd Generation DC Grid Access for Large Scale Offshore Wind Farms," 2015

[27] Siemens, "Fact Sheet: BorWin2 HVDC Platform," 2015. [Online]. Available:https://www.siemens.com/press/pool/de/feature/2013/energ y/2013-08-x-win/factsheet-borwin2-en.pdf. [Accessed $01 / 04$ /2019].

[28] Y. Tang, L. Ran, O. Alatise and P. Mawby, "Capacitor Selection for Modular Multilevel Converter," IEEE Transactions on Industry Applications, vol. 52, pp. 3279-3293, 72016.

[29] X. Gong, "A $3.3 \mathrm{kV}$ IGBT module and application in modular multilevel converter for HVDC," in 2012 IEEE International Symposium on Industrial Electronics, 2012.

[30] H. Wang and K. Ma, "IGBT technology for future high-power VSCHVDC applications," in 12th IET International Conference on AC and DC Power Transmission (ACDC 2016), 2016.

[31] K. Ilves, S. Norrga, L. Harnefors and H. Nee, "On Energy Storage Requirements in Modular Multilevel Converters," IEEE Transactions on Power Electronics, vol. 29, pp. 77-88, 12014.

[32] M. M. C. Merlin and T. C. Green, "Cell capacitor sizing in multilevel converters: cases of the modular multilevel converter and alternate arm converter," IET Power Electronics, vol. 8, pp. 350-360, 2015.

[33] F. Errigo, L. Chedot, P. Venet, P. Dworakowski and F. Morel, "Assessment of the Impact of Split Storage within Modular Multilevel Converter," 2019.

[34] E. Amankwah, A. Costabeber, A. Watson, D. Trainer, O. Jasim, J. Chivite-Zabalza and J. Clare, "The Series Bridge Converter (SBC): A hybrid modular multilevel converter for HVDC applications," in 2016 18 th European Conference on Power Electronics and Applications (EPE'16 ECCE Europe), 2016.

[35] J. D. Páez, D. Frey, J. Maneiro, S. Bacha and P. Dworakowski, "Overview of DC-DC Converters Dedicated to HVdc Grids," IEEE Transactions on Power Delivery, vol. 34, pp. 119-128, 22019. 